\title{
Protective Role of Tissue Transglutaminase in the Cell Death Induced by TNF- $\alpha$ in SH-SY5Y Neuroblastoma Cells
}

\author{
Soo-Mi Kweon ${ }^{\dagger,}$, Zee-Won Lee ${ }^{\ddagger}$, Sun-Ju Yi ${ }^{\dagger}$, Young-Myeong Kim ${ }^{\dagger}$, \\ Jeong-A Han ${ }^{\dagger}$, Sang-Gi Paik ${ }^{\S}$ and Kwon-Soo $\mathrm{Ha}^{\dagger}, *$ \\ Vascular System Research Center and Department of Molecular \& Cellular Biochemistry, \\ Kangwon National University School of Medicine, Chunchon, Kangwon 200-701, Korea \\ Cell Biology Team, Korea Basic Science Institute, Daejon 305-806, Korea \\ ${ }^{\S}$ Department of Biology, Chungnam National University, Daejon 305-764, Korea
}

Received 4 June 2003, Accepted 7 July 2003

Tissue transglutaminase (tTGase) regulates various biological processes, including extracellular matrix organization, cellular differentiation, and apoptosis. Here we report the protective role of tTGase in the cell death that is induced by the tumor necrosis factor $\alpha$ (TNF- $\alpha)$ and ceramide, a product of the TNF- $\alpha$ signaling pathway, in human neuroblastoma SH-SY5Y cells. Treatment with retinoic acid (RA) induced the differentiation of the neuroblastoma cells with the formation of extended neurites. Immunostaining and Western blot analysis showed the tTGase expression by RA treatment. TNF- $\alpha$ or $\mathrm{C}_{2}$ ceramide, a cell permeable ceramide analog, induced cell death in normal cells, but cell death was largely inhibited by the RA treatment. The inhibition of tTGase by the tTGase inhibitors, monodansylcadaverine and cystamine, eliminated the protective role of RA-treatment in the cell death that is caused by TNF- $\alpha$ or $\mathrm{C}_{2}$-ceramide. In addition, the co-treatment of TNF- $\alpha$ and cycloheximide decreased the protein level of tTGase and cell viability in the RA-treated cells, supporting the role of tTGase in the protection of cell death. DNA fragmentation was also induced by the co-treatment of TNF- $\alpha$ and cycloheximide. These results suggest that tTGase expressed by RA treatment plays an important role in the protection of cell death caused by TNF- $\alpha$ and ceramide.

Keywords: Cell death, $\mathrm{C}_{2}$-Ceramide, Retinoic acid, Tissue transglutaminase, Tumor necrosis factor $\alpha$

\footnotetext{
*To whom correspondence should be addressed.

Tel: 82-33-250-8833; Fax: 82-33-250-8807

E-mail: ksha@kangwon.ac.kr
}

\section{Introduction}

Tissue transglutaminase (tTGase) is a calcium-dependent enzyme that catalyzes the formation of amide bonds between the $\gamma$-carboxyl groups of glutamine residues and polypeptidebound lysine residues or primary polyamine (Greenberg et al., 1991). Recently, tTGase has attracted much attention, since there has been accumulating evidence suggesting the important roles of tTGase in various biological events. These events include the induction of apoptosis, cell adhesion and morphology change, neurodegenerative diseases, cell differentiation, cell growth, and oocyte maturation (Melino and Piacentini, 1998; Chen and Mehta, 1999; Antonyak et al., 2001; Im, 2001; Kim et al., 2001). It is reported that tTGase is involved in the stabilization of extracellular matrix by binding to extracellular matrix proteins (Chen and Mehta, 1999; Akimov et al., 2000). There have been reports suggesting the important role of tTGase in neurodegenerative diseases, including Huntingtons disease, even though there is a report on the contradictory role of tTGase in the formation of Huntington aggregates (Chun et al., 2001). Also, tTGase functions as a GTP-binding protein $\left(\mathrm{G}_{\alpha \mathrm{h}}\right)$, which mediates the activation of phospholipase $C \delta 1$ by the $\alpha_{1}$-adrenergic receptor (Iismaa et al., 2000).

It is reported that tTGase plays an important role in apoptosis by cross-linking various proteins, including core histones, glutathione S-transferase P1-1, retinoblastoma protein, troponin, and $\beta$-tubulin (Melino and Piacentini, 1998; Piredda et al., 1999). In SK-N-BE neuroblastoma cells, the overexpression of tTGase increased apoptosis in response to staurosporine and retinoic acid (RA) (Piredda et al., 1999). Induction of tTGase expression by RA treatment elevated apoptosis by apoptotic stimuli in U937 and vascular smooth muscle cells (Oliverio et al., 1999; Ou et al., 2000). Recently, however, there has been growing evidence to support the role 
of tTGase in cell survival rather than apoptosis (Antonyak et al., 2001; Boehm et al., 2002). It has been reported that apoptosis is inhibited by the RA-induced differentiation and expression of exogenous tTGase in HL 60 cells (Antonyak et al., 2001). By treatment with dexamethasone, the cell viability was much lower in thymocytes that were isolated from tTGase knockout mice than those from wild-type mice (Nanda et al., 2001). Therefore, it is necessary to elucidate the exact role of tTGase in apoptotic signaling.

The tumor necrosis factor (TNF), produced by activated macrophages, binds to TNF receptors and triggers a series of intracellular events that result in the activation of transcription factors, such as the nuclear factors $\mathrm{\kappa B}$ and c-Jun (Chen and Goeddel, 2002). TNF receptors also activate apoptotic signaling, including the TNF-receptor associated death domain, Fas-associated death domain, and caspases (Ashkenazi and Dixit, 1998; Declercq et al., 1998; Kimura et al., 1999). TNF activates the sphingomyelinase signaling pathway, which leads to a generation of ceramide that induces cell death through caspase 3 or the inhibition of the Akt kinase (Cuvillier et al., 1996; Yoshimura et al., 1998; Zhou et al., 1998). Although TNF signaling in cell death has been extensively researched as a model of receptor-mediated cellular signaling, the role of tTGase in TNF- $\alpha$ signaling is not understood.

In this report, we present a new function of tTGase in the cell death that is induced by TNF- $\alpha$ in SH-SY5Y human neuroblastoma cells. RA treatment inhibited cell death caused by TNF- $\alpha$ and ceramide, and the inhibitory effects were eliminated by tTGase inhibitors. The protective role of tTGase was also shown by the inhibition of tTGase synthesis. Therefore, it is likely that tTGase plays a key role in the protection from cell death that is induced by apoptotic signals in SH-SY5Y cells.

\section{Materials and Methods}

Chemicals and reagents TNF- $\alpha, \mathrm{C}_{2}$-ceramide ( $\mathrm{N}$-acetyl-Dsphingosine), all trans-retinoic acids, monodansylcadaverine, cystamine, apo-transferrin, and cycloheximide were purchased from the Sigma-Aldrich Co. (St. Louis, USA). The monoclonal

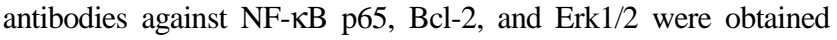
from Santa Cruz (Santa Cruz, USA). Tissue transglutaminase II mAb (CUB7402) was obtained from NeoMarker (Fremont, USA). Fetal bovine serum, bovine serum albumin, penicillin/streptomycin solution, and Dulbecco's modified Eagle's medium (DMEM) were from Gibco-BRL (Gaithersburg, USA).

Cell culture The SH-SY5Y human embryonic neuroblastoma cells were obtained from the Korea Cell Line Bank. They were maintained in DMEM containing $25 \mathrm{mM}$ HEPES, pH 7.4, $10 \%$ fetal bovine serum (v/v), 100 units $/ \mathrm{ml}$ penicillin, and $100 \mu \mathrm{g} / \mathrm{ml}$ streptomycin (growth medium) at $37^{\circ} \mathrm{C}$ in a humidified $\mathrm{CO}_{2}$ controlled (5\%) incubator. To verify the effects of agonists in the differentiated SH-SY5Y cells, the cells were differentiated with 10 $\mu \mathrm{M}$ of RA for $3 \mathrm{~d}$ in growth medium, and then the subconfluent cultures were washed twice with DMEM that was supplemented with $5 \mu \mathrm{g} / \mathrm{ml}$ apo-transferrin, $1 \mathrm{mg} / \mathrm{ml}$ bovine serum albumin, 25 $\mathrm{mM}$ HEPES, $\mathrm{pH} 7.4,100 \mu \mathrm{g} / \mathrm{ml}$ streptomycin, and $100 \mathrm{units} / \mathrm{ml}$ penicillin (serum-free medium). They were serum-starved for $18 \mathrm{~h}$ in all of the experiments.

Western blot analysis of tTGase To investigate the tTGase expression, total cell lysates were prepared with a modified radioimmunoprecipitation buffer $(50 \mathrm{mM}$ HEPES, $1 \%$ Triton X$100,150 \mathrm{mM} \mathrm{NaCl}, 10 \%$ glycerol, $0.5 \%$ NP-40, $4 \mathrm{mM} \mathrm{Na}_{3} \mathrm{VO}_{4}$, $200 \mathrm{mM} \mathrm{NaF}, 1 \mathrm{mM}$ EDTA, $0.1 \mathrm{mM}$ phenylmethanesufonyl fluoride, $10 \mu \mathrm{g} / \mathrm{ml}$ aprotinin and $10 \mu \mathrm{g} / \mathrm{ml}$ leupeptin). The protein extracts $(10-20 \mu \mathrm{g}$ per lane) were separated by $10 \%$ sodium dodecylsulphate (SDS)-polyacrylamide gel electrophoresis and transferred into a nitrocellulose membrane by using the wettransferring system (Bio-Rad Laboratories, Hercules, USA). The membrane was blocked and incubated with an anti-mouse tTGase monoclonal antibody $(1: 1000, \mathrm{v} / \mathrm{v})$. Horseradish peroxidaseconjugated anti-mouse IgG was used as a secondary antibody. The protein band of tTGase was then detected by the $\mathrm{ECL}^{\mathrm{TM}}$ system (Amersham Biosciences, Uppsala, Sweden).

Immunostaining of tTGase The cells were cultured on round coverslips for $2 \mathrm{~d}$ and incubated with $10 \mu \mathrm{M}$ of RA in a growth medium for $3 \mathrm{~d}$. The cells were then serum-starved for $18 \mathrm{~h}$ and treated with agonists. Next, the cells were fixed with $3.7 \%$ formaldehyde in Dulbeccos phosphate-buffered saline $(0.9 \mathrm{mM}$ $\mathrm{CaCl}_{2}, 2.7 \mathrm{mM} \mathrm{KCl}, 1.2 \mathrm{mM} \mathrm{KH} \mathrm{PO}_{4}, 0.49 \mathrm{mM} \mathrm{MgCl}, 138 \mathrm{mM}$ $\mathrm{NaCl}, 8.1 \mathrm{mM} \mathrm{Na}_{2} \mathrm{HPO}_{4}$ ) and permeabilized with $0.2 \%$ triton X100 in Dulbeccos phosphate-buffered saline for $30 \mathrm{~min}$ at room temperature. After incubating with a blocking solution $(20 \mathrm{mM}$ Tris, $\mathrm{pH} 7.6,138 \mathrm{mM} \mathrm{NaCl}, 0.1 \%$ triton $\mathrm{X}-100,2 \%$ bovine serum albumin) for $30 \mathrm{~min}$, the samples were incubated with a monoclonal tTGase antibody in the blocking solution $(1: 100, \mathrm{v} / \mathrm{v})$ for $2 \mathrm{~h}$ at room temperature. They were further incubated with fluorescein isothiocyanate-conjugated anti-mouse $\operatorname{IgG}(1: 200, \mathrm{v} / \mathrm{v})$ for $1 \mathrm{~h}$. The stained samples were mounted on slide glasses with GEL/MOUNT ${ }^{\mathrm{TM}}$ (Biomeda Corp., Foster City, USA) and observed by a confocal microscope with $488 \mathrm{~nm}$ of Ar laser and $515 \mathrm{~nm}$ of a longpass emission filter (Carl Zeiss 410, Jena, Germany).

Cell viability assay Cell viability was determined by counting the number of attached cells on a culture plate after treating the cells with agonists. The cells of $4 \times 10^{4}$ were plated onto a 48 -well culture plate, grown for $2 \mathrm{~d}$, and then incubated with $10 \mu \mathrm{M}$ of RA for $3 \mathrm{~d}$. After serum-starvation for $18 \mathrm{~h}$, the cells were treated with various agonists for the desired time. After treatment, each well was photographed at least 5 times by a digital camera. The attached cell numbers were counted from three randomly-selected transmitted images. Cell viability (\%) was determined and the cell numbers of the treated cells were compared to those of the control.

DNA fragmentation assay Genomic DNA fragmentation was determined by the modified procedures of Zhou et al. (1998), and Lee and Lim (2001). Briefly, the cells were grown in a $100 \mathrm{~mm}$ culture dish for $2 \mathrm{~d}$, harvested, and suspended in a lysis buffer (10 $\mathrm{mM} \mathrm{NaCl}, 1 \mathrm{mM}$ EDTA, $1 \%$ SDS, and 0.2\% Tris-HCl, $\mathrm{pH} 8.5$ ). 
Next, $0.1 \mathrm{mg} / \mathrm{ml}$ of proteinase $\mathrm{K}$ was added into the cell lysates and the cell lysates were incubated at $60^{\circ} \mathrm{C}$ for $2 \mathrm{~h}$. After adding $0.3 \mathrm{M}$ sodium acetate, the cell lysates were placed on ice for $30 \mathrm{~min}$ and centrifuged at $20,000 \times g$ for $15 \mathrm{~min}$. The supernatants were transferred into new tubes, precipitated with ethanol without salt, and centrifuged at $14,000 \mathrm{rpm}$ for $30 \mathrm{~min}$. The DNA pellet was washed with $70 \%$ ethanol, dissolved in $100 \mu \mathrm{l}$ of distilled water, and then incubated with $0.2 \mathrm{mg} / \mathrm{ml}$ of RNase A at $55^{\circ} \mathrm{C}$ for $1 \mathrm{~h}$. To analyze the DNA fragmentation, 10-20 $\mu \mathrm{g}$ of DNA was loaded into $1.5 \%$ agarose gel containing ethidium bromide. The DNA band was visualized under UV light.

\section{Results}

Induction of tTGase by RA in SH-SY5Y cells In order to investigate the protective role of tTGase in cell death that is induced by TNF- $\alpha$, the SH-SY5Y cells were initially treated with RA for $3 \mathrm{~d}$, because RA effectively induces the tTGase expression via nuclear receptors in various cell types (Singh et al., 1998; Antonyak et al., 2001; Tucholski et al., 2001). By the incubation with RA, the SH-SY5Y cells were differentiated into neuron-like cells with extended neurites (Fig. 1A). We then studied whether RA-induced differentiation could induce the tTGase expression in the neuroblastoma cells by immunostaining and Western blotting. When the cells were labeled with the monoclonal anti-tTGase antibody and observed by a confocal microscope, the amount of tTGase was largely elevated by the RA treatment, particularly in the cytosolic region (Fig. 1B). This was consistent with a previous report (Lesort et al., 1998). The tTGase expression by RA was also shown by Western blotting analysis using the monoclonal antibody (Fig. 1C). As expected from the confocal microscopic results, a remarked increase of tTGase was observed in the cells that were treated with RA when compared to the control cells. However, the RA treatment caused no significant change in the protein levels that were related to cell proliferation or anti-apoptotic function, such as Bcl-2, Erk1/2, and NF- $\kappa B$ p65. The treatment with RA, therefore, resulted in the tTGase expression with the formation of extended neurites in the SHSY5Y neuroblastoma cells.

Inhibitory effect of RA treatment on the cell death by TNF- $\boldsymbol{\alpha}$ and $\mathbf{C}_{2}$-ceramide Next, we investigated the effect of the tTGase expression on the cell death induced by TNF- $\alpha$. The SH-SY5Y cells were differentiated with RA for $3 \mathrm{~d}$. Cell death was determined by a microscopic observation of the cell shrinkage and detachment from the culture plates. In the undifferentiated control cells, the cells began to shrink and detach from the culture plates at $3 \mathrm{~h}$ after incubation with TNF- $\alpha$. Within $24 \mathrm{~h}$, a large number of cells were detached from the culture plates (Fig. 2A). However, TNF- $\alpha$ had no effect on the cells that were differentiated with RA. Reportedly, TNF- $\alpha$ activates the sphingomyelinase-signaling pathway, leading to a generation of ceramide that induces cell death through the activation of caspase 3 or inhibition of Akt kinase (Cuvillier et al., 1996; Yoshimura et al., 1998; Zhou et al., 1998). Therefore, we also investigated the effect of cell differentiation on the cell death that is induced by $\mathrm{C}_{2^{-}}$ ceramide, a cell-permeable ceramide analogue. As shown in Fig. 2A, a large number of cells were detached after being shrunk within $24 \mathrm{~h}$ by $\mathrm{C}_{2}$-ceramide in undifferentiated cells, but no cells were affected by $\mathrm{C}_{2}$-ceramide in the RA-treated cells. Considering the tTGase expression by the RA treatment, these results indicate the possible role of tTGase in the prevention of cell death that is caused by TNF- $\alpha$ and $\mathrm{C}_{2^{-}}$ ceramide.

Cell viability was also investigated by determining the percentage of normal (un-shrunken) cells that was attached on the culture plates after incubation by TNF- $\alpha$ or $\mathrm{C}_{2}$-ceramide for $24 \mathrm{~h}$. As shown in Fig. 2B, TNF- $\alpha$ and $\mathrm{C}_{2}$-ceramide significantly decreased the cell viabilities by 47 and $18 \%$ of the control level, respectively, in undifferentiated cells. In contrast, the RA treatment enhanced cell viability when compared to the undifferentiated cells. Also, TNF- $\alpha$ and $\mathrm{C}_{2}-$ ceramide had no significant effect on the viability of the cells
(A)

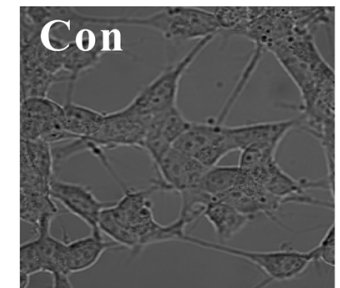

(B)

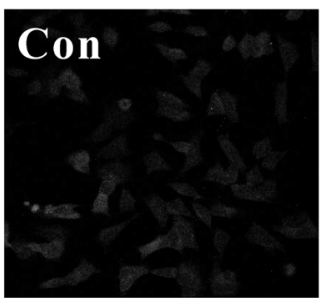

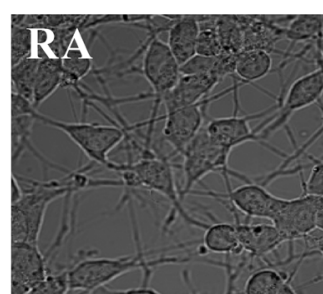

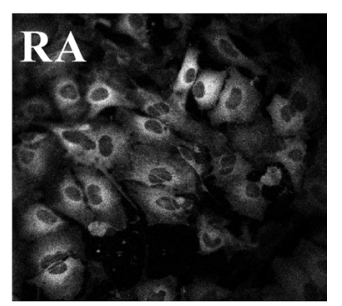

(C)

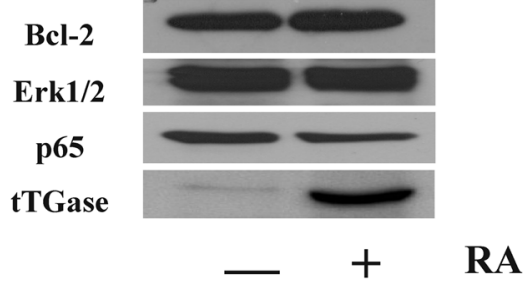

Fig. 1. Changes of cell morphology (A), tTGase expression (B), and protein expression (C) by RA-treatment in SH-SY5Y cells. The cells were treated with vehicle (Con) and $10 \mu \mathrm{M}$ of RA for $3 \mathrm{~d}$ in growth medium. (A) Morphology of neuroblastoma cells incubated with control (Con) or retinoic acid (RA). The bar is 10 $\mathrm{mm}$. (B) The cells were stained with monoclonal tTGase antibody (CUB 7402) and observed by a confocal microscope as described in Materials and Methods. (C) The proteins were extracted from the cells that were treated with vehicle or RA, and separated with $10 \%$ SDS-PAGE. Then, Bcl-2, Erk1/2, NF$\mathrm{\kappa B}$ (p65), and tTGase were detected by Western blotting analysis as described in Materials and Methods. 
(A)
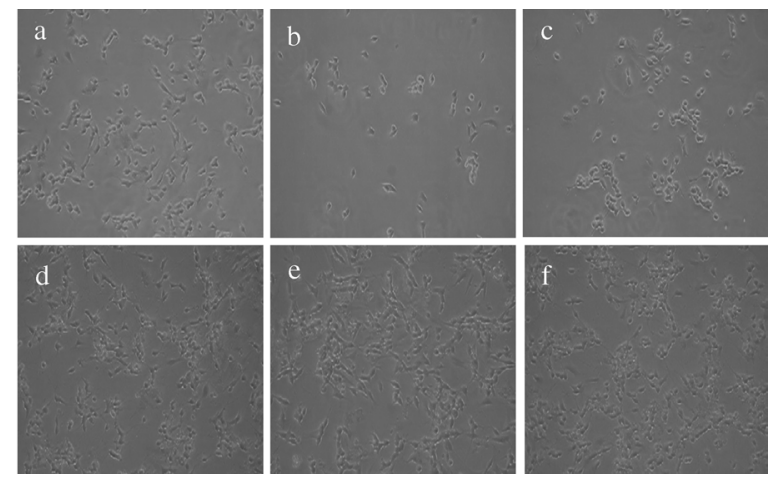

(B)

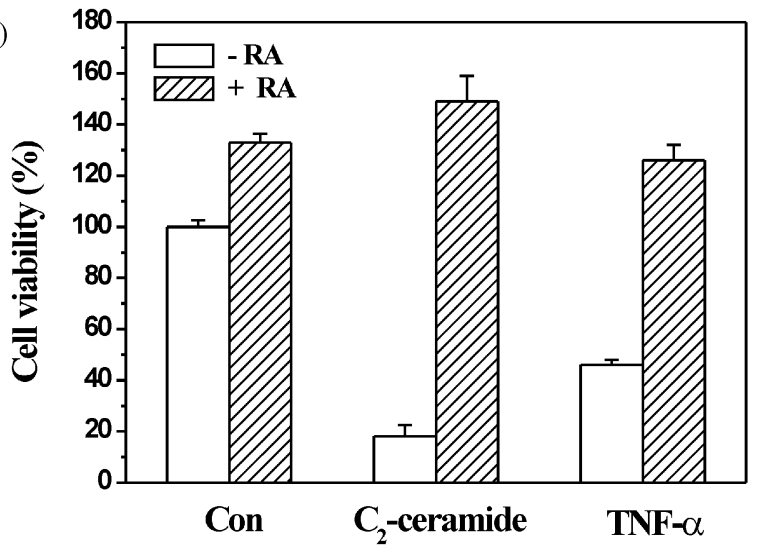

Fig. 2. Effect of RA-treatment on the viability of SH-SY5Y cells treated with $\mathrm{C}_{2}$ ceramide and TNF- $\alpha$. (A) The cells were incubated with vehicle $(\mathrm{a}, \mathrm{b}, \mathrm{c})$ or $10 \mu \mathrm{M} \mathrm{RA}(\mathrm{d}, \mathrm{e}, \mathrm{f})$ for $3 \mathrm{~d}$, then serum-starved for $18 \mathrm{~h}$. The cells were treated with the control (a, d), $20 \mathrm{mM} \mathrm{C}_{2}$-ceramide (b, e), and $10 \mathrm{ng} / \mathrm{ml} \mathrm{TNF-} \alpha$ (c, f) for $24 \mathrm{~h}$. The transmitted images were then taken by a digital camera. (B) Three transmitted images were randomly selected from each treatment, and the attached cell numbers were counted as described in Materials and Methods. Cell viability (\%) was determined by comparing the cell numbers of the control with those of the treated cells. Data are means \pm S.E. from three separate experiments.

that were differentiated with RA. These results suggest that the RA treatment caused cellular resistance against the cell death that is induced by TNF- $\alpha$ and $\mathrm{C}_{2}$-ceramide in SH-SY5Y cells.

Role of tTGase in protection against cell death by TNF- $\alpha$ or $\mathbf{C}_{2}$-ceramide Our previous results showed that the RA treatment induced the tTGase expression and protected it from the cell death that is induced by TNF- $\alpha$ and $\mathrm{C}_{2}$-ceramide. Thus, we investigated whether tTGase was responsible for the protection against cell death by TNF- $\alpha$ and $\mathrm{C}_{2}$-ceramide in RA-treated cells. The tTGase role was studied by preincubation with tTGase inhibitors, monodansylcadaverine, and cystamine (Ou et al., 2000; Kim et al., 2001). As shown in Fig. 3, monodansylcadaverine and cystamine largely reversed the protection from cell death in response to TNF- $\alpha$ and $\mathrm{C}_{2}$-ceramide. However, the inhibitors alone had no

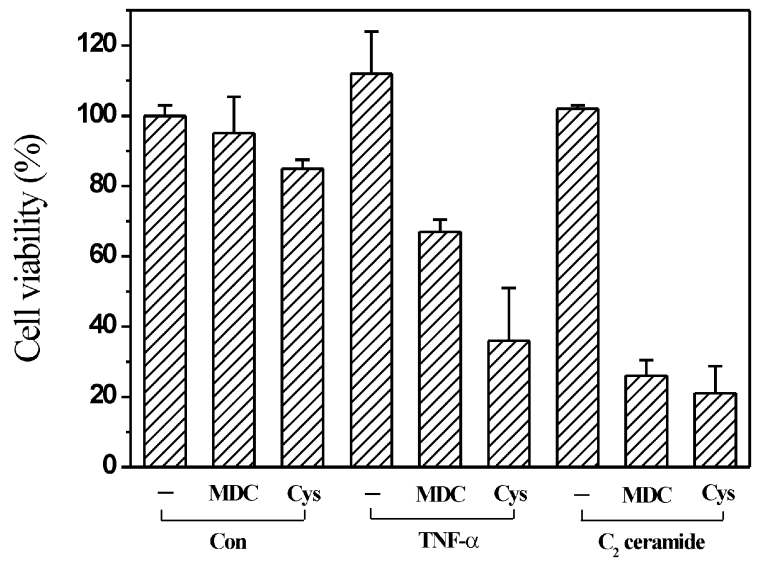

Fig. 3. Effect of tTGase inhibitors on the viability of SH-SY5Y cells. The cells were incubated with $10 \mathrm{mM}$ RA for $3 \mathrm{~d}$ and serum-starved for $18 \mathrm{~h}$. The cells were then preincubated with vehicle (-), $20 \mu \mathrm{M}$ monodansylcadaverine (MDC), or cystamine (Cys), and treated with the control (Con), TNF- $\alpha$, and $\mathrm{C}_{2}$ ceramide with for $18 \mathrm{~h}$. Cell viability was determined as described in the legend of Fig. 2. Data are means \pm S.E. from three separate experiments.

significant effect on the cell viability. These results suggest that the cell protection that was caused by the RA treatment contributed to the tTGase expression.

To confirm the possible tTGase role in cell protection, the tTGase protein level, cell viability, and DNA fragmentation were investigated after co-treatment of the RA-treated cells with TNF- $\alpha$ and cycloheximide (Fig. 4). Cycloheximide inhibits protein synthesis and induces cell death in many cell types (Setkov et al., 1992; Suzuki et al., 1992; Tang et al., 1999). The tTGase protein level was investigated by Western blotting after incubation with TNF- $\alpha$ and cycloheximide. There was no change in the tTGase protein level until $3 \mathrm{~h}$. However, the tTGase protein level was largely decreased by the co-treatment of TNF- $\alpha$ and cycloheximide for $18 \mathrm{~h}$ with no change by TNF- $\alpha$ or cycloheximide alone (Fig. 4A). We then investigated the effect of cycloheximide on the cell viability by TNF- $\alpha$. The co-treatment of TNF- $\alpha$ and cycloheximide decreased cell viability to about $40 \%$ of the control level in the RA-differentiated neuroblastoma cells (Fig. 4B). However, cycloheximide alone had no significant effect on the tTGase level and cell viability (data not shown). In addition, DNA fragmentation was observed within $48 \mathrm{~h}$ by the co-treatment of TNF- $\alpha$ and cycloheximide, but not by TNF- $\alpha$ alone (Fig. 4C). These results suggest that the tTGase expression by RA is responsible for the protection from apoptotic cell death that is induced by TNF- $\alpha$.

\section{Discussion}

In this report, we demonstrated the protective role of tTGase in the death signaling that is induced by TNF- $\alpha$ signaling in 
(A)

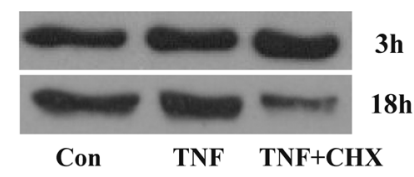

(B)

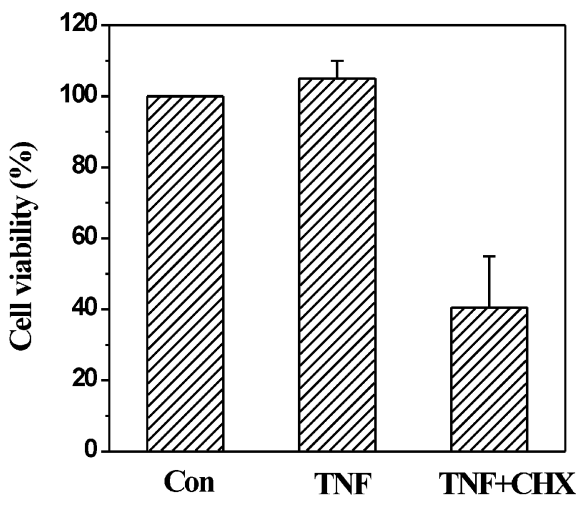

(C)

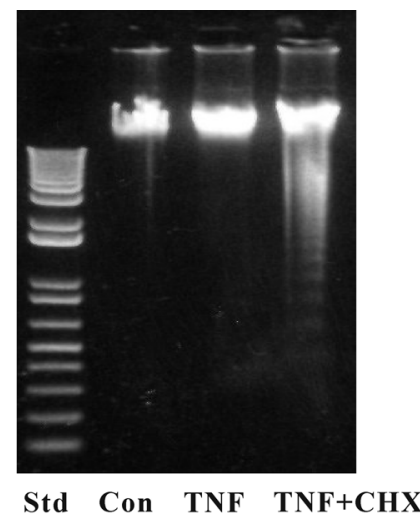

Fig. 4. Effect of cycloheximide on tTGase expression (A), cell viability (B), and DNA fragmentation (C) by TNF- $\alpha$ in SHSY5Y cells. The cells were incubated with $10 \mathrm{mM}$ RA for $3 \mathrm{~d}$ and serum-starved for $18 \mathrm{~h}$. The cells were then treated with the control (Con), TNF- $\alpha$ alone (TNF), or TNF- $\alpha$ and $10 \mu \mathrm{g} / \mathrm{ml}$ cycloheximide $(\mathrm{TNF}+\mathrm{CHX})$ for $18 \mathrm{~h}$. (A) The proteins were extracted at $3 \mathrm{~h}$ and $18 \mathrm{~h}$ after treatment, and tTGase was detected by a Western blotting analysis. (B) Cell viability assay. Cell viability was determined as described in Materials and Methods. Data are means \pm S.E. from three separate experiments. (C) DNA fragmentation assay. DNA was extracted, separated by $1.5 \%$ agarose gel containing ethidium bromide, and then visualized under UV light as described in Materials and Methods. Std, DNA 1 kb marker.

SH-SY5Y cells. RA treatment induced the tTGase expression, which was verified by Western blotting and confocal microscopic observation. The protective role of tTGase was shown by three different approaches. First, TNF- $\alpha$-induced cell death was largely inhibited by RA treatment. Similar results were also obtained by ceramide, which is generated by the sphingomyelin signaling of TNF- $\alpha$ (Cuvillier et al., 1996; $\mathrm{Xu}$ et al., 1998). Secondly, the protective role of the RA treatment in the cell death that is induced by TNF- $\alpha$ or ceramide was significantly eliminated by the tTGase inhibitors, monodansylcadaverine and cystamine. In addition, cell viability was decreased when the tTGase protein level was reduced by co-treatment of TNF- $\alpha$ and cycloheximide.

It was reported that tTGase is an important factor for apoptosis in various cells, including human promonocytic and vascular smooth muscle cells (Melino and Piacentini, 1998; Oliverio et al., 1999; Ou et al., 2000). The U937 promonocytic cells that were treated with RA, which showed an elevated tTGase expression, were susceptible to apoptosis. In addition, cell death significantly decreased by the inhibition of the tTGase expression or the expression of the antisense tTGase gene (Oliverio et al., 1999). The tTGase expression by the RA-treatment also elevated cell death in vascular smooth muscle cells (Ou et al., 2000). Recently, however, there have been reports that tTGase is involved in cell survival rather than cell death (Antonyak et al., 2001; Antonyak et al., 2002; Boehm et al., 2002). The differentiation of the HL60 and NIH 3T3 cells with RA, which increased the activity and expression of tTGase through phosphoinositide 3-kinase, inhibited apoptosis that is caused by $\mathrm{N}$-(4-hydroxyphenyl) retinamide (Antonyak et al., 2001; Antonyak et al., 2002). The inhibition of apoptosis by the RA treatment was also explained by the transamidation of the retinoblastoma protein (Boehm et al., 2002). Our results showed the protective role of tTGase against cell death by TNF- $\alpha$. Thus, it is likely that tTGase has dual functions, cell survival and death, which might be dependent on the type of cell system or extracellular signal.

TNF- $\alpha$ induced cell death in the RA-treated cells when cycloheximide was co-treated. By the same treatment, the tTGase protein level significantly decreased and DNA fragmentation was clearly observed within $48 \mathrm{~h}$, which is a representative phenomenon of apoptosis. Reportedly, TNF rarely triggers apoptosis unless protein synthesis is blocked (Xu et al., 1998). This suggests that cellular factors (for

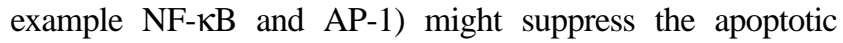
stimulus that is generated by TNF (Ashkenazi and Dixit, 1998). We presented here that the RA treatment activated the tTGase expression with no significant changes in the protein levels that are related to the cell proliferation or anti-apoptotic function, such as Bcl-2, Erk1/2, and NF- $\mathrm{B}$ p65. Therefore, the tTGase expression could be a prerequisite condition for protection against cell death. Also, the continuous tTGase expression might confer cellular resistance against death stimuli, such as TNF- $\alpha$ and $\mathrm{C}_{2}$-ceramide.

What is the possible mechanism by which tTGase protects against cell death that is caused by TNF- $\alpha$ ? It is well known that TNF induces cell death by apoptotic signaling, including the TNF-receptor associated death domain, Fas-associated death domain, and caspases (Ashkenazi and Dixit, 1998; Declercq et al., 1998; Kimura et al., 1999). TNF is also known to trigger anti-apoptotic signaling, resulting in the activation of transcription factors, nuclear factor $\mathrm{kB}$, and c-Jun (Chen and Goeddel, 2002). TNF- $\alpha$ also activates the sphingomyelinase signaling pathway, leading to a generation of ceramide that induces cell death through caspase 3 or the 
inhibition of the Akt kinase (Cuvillier et al., 1996; Yoshimura et al., 1998; Zhou et al., 1998). It is also reported that TNF- $\alpha$ generated intracellular ROS by a phospholipase $\mathrm{A}_{2}$ cascade (Woo et al., 2000). In this work, we present evidence suggesting the anti-apoptotic role of tTGase in the cell signaling by TNF- $\alpha$. Thus, it is possible to predict that tTGase inhibited TNF- $\alpha$-stimulated cell death by two possible mechanisms, the direct inhibition of the apoptotic signaling pathway by tTGase, or the indirect inhibition of the apoptotic pathway through the activation of the anti-apoptotic pathway. However, it is necessary to elucidate the tTGase role(s) in TNF- $\alpha$ signaling.

In summary, tTGase has a very important function to regulate cellular fate, death, or survival, but its exact mechanisms are not yet well understood. In this report, we provided evidence to demonstrate the function of tTGase in cellular protection against death signaling that is induced by TNF- $\alpha$ and ceramide in neuroblastoma cells.

Acknowledgments This work was supported in part by grants from the Korea Science and Engineering Foundation (1999-2-20700-004-5) and Vascular System Research Center of KOSEF.

\section{References}

Akimov, S. S., Krylov, D., Flrischman, L. F. and Belkin, A. M. (2000) Tissue transglutaminase is an integrin-binding adhesion coreceptor for fibronectin. J. Cell. Biol. 148, 825-838.

Antonyak, M. A., Boehm, J. E. and Cerione, R. A. (2002) Phosphoinositide 3-Kinase activity is required for retinoic acidinduced expression and activation of the tissue transglutaminase. J. Biol. Chem. 277, 14712-14716.

Antonyak, M. A., Singh, U., Lee, D. A., Boehm, J. E., Combs, C., Zgola, M. M., Page, R. L. and Cerione, R. A. (2001) Effects of tissue transglutaminase on retinoic acid-induced cellular differentiation and protection against apoptosis. J. Biol. Chem. 276, 33582-33587.

Ashkenazi, A. and Dixit, V. M. (1998) Death receptors: signaling and modulation. Science 281, 1305-1308.

Boehm, J. E., Singh, U., Combs, C., Antonyak, M. A. and Cerione, R. A. (2002) Tissue transglutaminase protects against apoptosis by modifying the tumor suppressor protein $\mathrm{p} 110 \mathrm{Rb}$. J. Biol. Chem. 277, 20127-20130.

Chen, G. and Goeddel, D. V. (2002) TNF-R1 signaling: a beautiful pathway. Science 296, 1634-1635.

Chen, J. S. K. and Mehta, K. (1999) Tissue transglutaminase: an enzyme with a split personality. Intl. J. Biochem. Cell. Biol. 31, 817-836.

Chun, W., Lesort, M., Tucholski, J., Ross, C. A. and Johnson, G. V. W. (2001) Tissue transglutaminase does not contribute to the formation of mutant Huntington aggregates. J. Cell. Biol. 153, 25-34.

Cuvillier, O., Pirianov, G., Kleuser, B., Vanek, P. G., Coso, O. A., Gutkind, S. and Spiegel, S. (1996) Suppression of ceramidemediated programmed cell death by sphingosine-1-phosphate.
Nature 381, 800-803.

Declercq, W., Denecker, G., Fiers, W. and Vandenabeele, P. (1998) Cooperation of both TNF receptors in inducing apoptosis: involvement of the TNF receptor-associated factor binding domain of the TNF receptor 75. J. Immunol. 161, 390-399.

Greenberg, C. S., Birckbichler, P. J. and Rice, R. H. (1991) Transglutaminase: multifunctional cross-linking enzymes that stabilize tissues. FASEB J. 5, 3071-3077.

Iismaa, S. E., Wu, M. J., Nanda, N., Church, W. B. and Graham, R. M. (2000) GTP binding and signaling by $\mathrm{G}_{\mathrm{h}} /$ transglutaminase II involves distinct residues in a unique GTPbinding pocket. J. Biol. Chem. 275, 18259-18266.

Im, M. J. (2001) Regulation of a novel guanine nucleotide binding protein tissue transglutaminase $\left(\mathrm{G \alpha}_{\mathrm{h}}\right)$. J. Biochem. Mol. Biol. 34, 95-101.

Kim, S. -W., Lee, Z. -W., Lee, C., Im, K. -S. and Ha, K. -S. (2001) The role of tissue transglutaminase in the germinal vesicle breakdown of mouse oocytes. Biochem. Biophys. Res. Commun. 286, 229-234.

Kimura, K., Bowen, C., Spiegel, S. and Gelmann, E. P. (1999) Tumor necrosis factor-alpha sensitizes prostate cancer cells to gamma-irradiation-induced apoptosis. Cancer Res. 59, 16061614.

Lee, J. C. and Lim, K. T. (2001) Inhibitory effects of the ethanol extract of Ulmus davidiana on apoptosis induced by glucoseglucose oxidase and cytokine production in cultured mouse primary immune cells. J. Biochem. Mol. Biol. 34, 463-471.

Lesort, M., Attanavanich, K., Zhang, J. and Johnson, G. V. (1998) Distinct nuclear localization and activity of tissue transglutaminase. J. Biol. Chem. 273, 11991-11994.

Melino, G. and Piacentini, M. (1998) Tissue transglutaminase in cell death: a downstream or a multifunctional upstream effector? FEBS Lett. 430, 59-63.

Nanda, N., Iismaa, S., Owens, A., Husain, A., Mackay, F. and Graham, R. (2001) Targeted inactivation of $\mathrm{G}_{\mathrm{h}} / \mathrm{tissue}$ transglutaminase II. J. Biol. Chem. 276, 20673-20678.

Oliverio, S., Amendola, A., Rodolfo, C., Spinedi, A. and Piacentini, M. (1999) Inhibition of tissue transglutaminase increases cell survival by preventing apoptosis. J. Biol. Chem. 274, 34123-34128.

Ou, H., Haendeler, J., Aebly, M. R., Kelly, L. A., Cholewa, B. C., Koike, G., Kwitek-Black, A., Jacob, H. J., Berk, B. C. and Miano, J. M. (2000) Retinoic acidinduced tissue transglutaminase and apoptosis in vascular smooth muscle cells. Circ. Res. 87, 881-887.

Piredda, L., Farrace, M. G., Bello, M. L., Malorni, W., Melino, G., Petruzzelli, R. and Piacentini, M. (1999) Identification of tissue transglutaminase binding proteins in neural cells committed to apoptosis. FASEB J. 13, 355-364.

Setkov, N. A., Kazakov, V. N., Rosenwald, I. B., Makarova, G. F. and Epifanova, O. I. (1992) Protein synthesis inhibitors, like growth factors, may render resting 3T3 cells competent for DNA synthesis: a radioautographic and cell fusion study. Cell Prolif. 25, 181-191.

Singh, U., Li, Q. and Cerione, R. A. (1998) Identification of the eukaryotic initiation factor $5 \mathrm{~A}$ as a retinoic acid-stimulated cellular binding partner for tissue transglutaminase II. J. Biol. Chem. 273, 1946-1950.

Suzuki, N., Suzuki, T., Uchida, A., Thompson, E. A. and Hosoya, T. (1992) Effect of dexamethasone on nucleolar casein kinase 
II activity and phosphorylation of nucleolin in lymphosarcoma P1798 cells. J. Steroid. Biochem. Mol. Biol. 42, 305-312.

Tang, D., Lahti, J. M., Grenet, J. and Kidd, V. J. (1999) Cycloheximide-induced T-cell death is mediated by a Fasassociated death domain-dependent mechanism. J. Biol. Chem. 274, 7245-7252.

Tucholski, J., Lesort, M. and Johnson, G. V. (2001) Tissue transglutaminase is essential for neurite outgrowth in human neuroblastoma SH-SY5Y cells. Neuroscience 102, 2481-2491.

Woo, C. H., Eom, Y. W., Yoo, M. H., You, H. J., Han, H. J., Song, W. K., Yoo, Y. J., Chun, J. S. and Kim, J. H. (2000) Tumor necrosis factor- generates reactive oxygen species via a cytosolic phospholipase $\mathrm{A}_{2}$-linked cascade. J. Biol. Chem. 275, 32357-32362.
Xu, J., Yeh, C. H., Chen, S., He, L., Sensi, S. L., Canzoniero, L. M. T., Choi, D. W. and Hsu, C. Y. (1998) Involvement of de Novo ceramide biosynthesis in tumor necrosis factor- $\alpha /$ cycloheximide-induced cerebral endothelial cell death. J. Biol. Chem. 273, 16521-16526.

Yoshimura, S. I., Banno, Y., Nakashima, S., Takenaka, K., Sakai, H., Nishimura, Y., Sakai, N., Shimizu, S., Eguchi, Y., Tsujimoto, Y. and Nozawa, Y. (1998) Ceramide formation leads to caspase-3 activation during hypoxic PC12 cell death. J. Biol. Chem. 273, 6921-6927.

Zhou, H., Summers, S., Birnbaum, M. and Pittman, R. (1998) Inhibition of Akt kinase by cell-permeable ceramide and its implications for ceramide-induced apoptosis. J. Biol. Chem. 273, 16568-16575. 